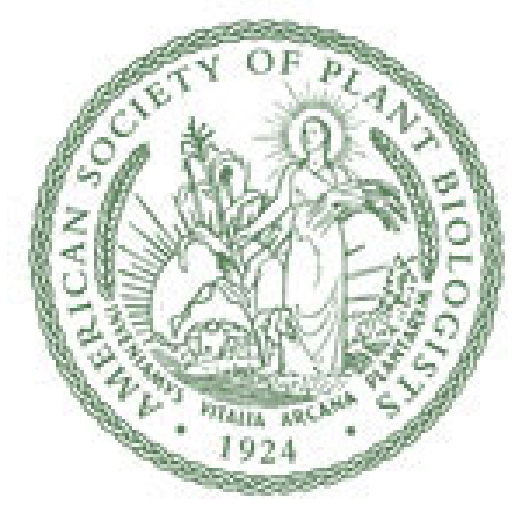

Kinetic Determination of the Genome Size of the Pea Author(s): William R. Pearson, Shelley L. Smith, Jung-Rung Wu and James Bonner Source: Plant Physiology, Vol. 62, No. 1 (Jul., 1978), pp. 112-115

Published by: American Society of Plant Biologists (ASPB)

Stable URL: http://www.jstor.org/stable/4265383

Accessed: 16/12/2014 01:47

Your use of the JSTOR archive indicates your acceptance of the Terms \& Conditions of Use, available at http://www.jstor.org/page/info/about/policies/terms.jsp

JSTOR is a not-for-profit service that helps scholars, researchers, and students discover, use, and build upon a wide range of content in a trusted digital archive. We use information technology and tools to increase productivity and facilitate new forms of scholarship. For more information about JSTOR, please contact support@ jstor.org. 


\title{
Kinetic Determination of the Genome Size of the $\mathrm{Pea}^{1}$
}

\author{
Received for publication October 18, 1977 and in revised form February 23, 1978
}

\author{
William R. Pearson, Shelley L. Smith, Jung-Rung Wu, and James Bonner \\ Division of Biology, California Institute of Technology, Pasadena, California 91125
}

\begin{abstract}
Renaturation of pea (Pisum sativum) DNA has been used to estimate the size of the pea genome and the fraction of pea DNA containing repeated DNA sequences. Pea DNA renaturation and single copy tracer renaturation indicate that the size of the pea genome is 0.5 picograms. More than $70 \%$ of pea DNA sequences are repeated from 100 to 5,000 times.
\end{abstract}

In the past few years, substantial data on the organization of repeated and single copy sequences in animal DNAs have been accumulated. There have been relatively few studies on DNA sequence organization in plants. Most of the plants studied, including cotton (14), wheat, rye, and barley (11), tobacco (16), and peas (12) have a large repetitive fraction (40-70\% repeated sequences) while the single copy sequence lengths are 1,000 to 3,000 nucleotides long $(11,14,16)$, similar to most of the animal genomes (5). The distributions of long and short (300-nucleotide) repeated sequences pattern seen in most animals have been found in tobacco and peas but the repeated sequences of the cotton genome (14) are longer than 1,000 nucleotides in length.

We have measured the fraction of repetitive and single copy DNA in the pea genome. Our measurements on the single copy rate of reassociation suggest that the size of the pea genome is substantially smaller than previous reports $(1,9,12,13)$. More than $70 \%$ of the DNA sequences in the pea are repeated with an average of about 500 -fold and the rate constant for the single copy reassociation is 0.00215 , corresponding to a genome size of $0.5 \mathrm{pg}$ according to our best estimates.

\section{MATERIALS AND METHODS}

Isolation of Crude Chromatin from Pea Embryos. Alaskan peas $(45.3 \mathrm{~kg})$ ( Pisum sativum) were germinated for 3 days. Pea embryos $(10.42 \mathrm{~kg})$ were isolated using a system for large scale preparation of pea embryo tissue. Embryos were stored at $-20 \mathrm{C}$.

For preparation of crude chromatin, $1.8 \mathrm{~kg}$ of frozen embryos were homogenized in a 1-gallon Waring Blendor in $0.25 \mathrm{M}$ sucrose, $50 \mathrm{mM}$ Tris ( $\mathrm{pH} 8), 1 \mathrm{mM} \mathrm{MgCl}$, and centrifuged at 5,000g in a Sorvall GSA rotor for $30 \mathrm{~min}$. The crude nuclear pellet was separated from a starch pellet, resuspended in grinding buffer, and centrifuged at $10,000 \mathrm{~g}$ for $15 \mathrm{~min}$. The nuclear pellet was again separated from the starch pellet, resuspended in $50 \mathrm{mM}$ Tris (pH 8), and centrifuged at $10,000 \mathrm{~g}$ for 20 .

Isolation of DNA. The crude chromatin pellet was suspended in $0.1 \mathrm{M}$ Tris, $0.1 \mathrm{M}$ EDTA ( $\mathrm{pH} 8.5$ ) and SDS added to $1 \%$. The viscous mixture was brought to $37 \mathrm{C}$ and incubated with $50 \mu \mathrm{g} / \mathrm{ml}$ of pronase (Calbiochem grade B) until the DNA went into solu-

${ }^{1}$ This work was supported in part by United States Public Health Service Training Grant GM00086 and in Research Grants GM13762 and GM20927. tion. The DNA was extracted twice with a mixture of phenolchloroform-isoamyl alcohol (25:24:1) and extracted twice with chloroform-isoamyl alcohol (24:1). The DNA was then precipitated at room temperature in 2.5 volume of $95 \%$ ethanol and allowed to dissolve overnight in $0.05 \mathrm{M}$ Tris, $0.01 \mathrm{M}$ EDTA $(\mathrm{pH}$ 8.5).

Once in solution, the DNA was digested with RNase A (preincubated for $10 \mathrm{~min}$ at $95 \mathrm{C}$ ) at $50 \mu \mathrm{g} / \mathrm{ml}$ for $90 \mathrm{~min}$ at $37 \mathrm{C}$ and digested with $200 \mu \mathrm{g} / \mathrm{ml}$ of pronase (preincubated for $45 \mathrm{~min}$ at $37 \mathrm{C}$ ) for $90 \mathrm{~min}$ at $37 \mathrm{C}$. The DNA was then extracted with chloroform-isoamyl alcohol (24:1) three times and reprecipitated with ethanol. The DNA was redissolved and reprecipitated with ethanol.

The DNA was sheared to an average 350 nucleotides by three passes through a French pressure cell at 50000 p.s.i. and passed over Chelex-100 (Bio-Rad) before renaturation.

Preparation of ${ }^{125}$ I-labeled DNA. Pea DNA (350 nucleotides) was iricubated to Cot 400 and the single strand fraction (15\%) isolated on HAP. ${ }^{2}$ This material was concentrated and labeled with ${ }^{125}$ I using a modified Commerford (4) procedure (6).

Renaturation of DNA. DNA fragments were denatured at $100 \mathrm{C}$ and renatured in $0.12 \mathrm{M} \mathrm{Na}$-phosphate buffer $(\mathrm{pH} \mathrm{6.8)}$ ) at $60 \mathrm{C}$ and $70 \mathrm{C}$ and in $0.48 \mathrm{M} P \mathrm{~PB}$ at $71 \mathrm{C}$ and $81 \mathrm{C}$. Samples were then diluted to $0.03 \mathrm{M} \mathrm{PB}$ and passed over HAP at $60 \mathrm{C}$ to check for degradation. Samples with more than $10 \%$ of the DNA not binding to HAP in $0.03 \mathrm{M} \mathrm{PB}$ were discarded. The single strand fraction was then eluted with $0.12 \mathrm{M} P B$ and the double strand fraction denatured at $100 \mathrm{C}$ and eluted with $0.12 \mathrm{M} \mathrm{PB}$.

Optical renaturation was carried out in a Gilford 2400 spectrophotometer equipped with a water-jacketed sample compartment. Samples were denatured, loaded into the sample compartment, and the decrease in hyperchromicity monitored.

Renaturation of ${ }^{125}$ I-labeled DNA was carried out in $0.12 \mathrm{M}$ PB at $60 \mathrm{C}$ and in $0.48 \mathrm{M} \mathrm{PB}$ at $65 \mathrm{C}$. After renaturation, samples were diluted to $0.12 \mathrm{M}$ PB and passed over HAP in $0.12 \mathrm{M}$ PB. The double strand fraction was eluted with $0.4 \mathrm{M} P B$. The renaturation of the driver DNA was followed optically; the fraction of the ${ }^{125} \mathrm{I}$ tracer in hybrid was measured by trichloroacetic acid precipitation of the HAP fractions.

Fits of second order components to the data were calculated using a nonlinear least squares computer program (10).

\section{RESULTS}

We have used three renaturation assays to determine the fraction of single copy and the single copy rate constant in the pea genome. HAP binding and decrease in hyperchromicity assays of total pea DNA provide measures of the single copy fraction and rate. In addition, a slowly renaturing fraction has been isolated and labeled to search for a small fraction, high complexity component. The renaturations of total DNA were carried out at

\footnotetext{
${ }^{2}$ Abbreviations: PB: 0.12 M Na-phosphate buffer ( $\mathrm{pH} \mathrm{6.8);} \mathrm{HAP:} \mathrm{hy-}$ droxyapatite; Cot: initial concentration of DNA in mol of nucleotide/liter multiplied by time in sec.
} 
standard criterion (60 C, $0.12 \mathrm{M} \mathrm{PB})$ and at a higher criterion (70 C, 0.12 for HAP assay, $66 \mathrm{C}, 0.12$ for optical assay) to look for repetitive fractions caused by very poorly matched sequences.

HAP Cot Curves. Figure $1, A$ and $B$ shows the renaturation of 350-nucleotide-long pea DNA fragments at $60 \mathrm{C}$ and $70 \mathrm{C}$. The $60 \mathrm{C}\left(\mathrm{T}_{\mathrm{m}}-25 \mathrm{C}\right)$ incubations were carried out at $60 \mathrm{C}$ in $0.12 \mathrm{M}$ PB $\left(0.18 \mathrm{M} \mathrm{Na}^{+}\right)$and at $71 \mathrm{C}$ for $0.41 \mathrm{M}$ PB (2). The $70 \mathrm{C}\left(\mathrm{T}_{\mathrm{m}}-\right.$ $15 \mathrm{C})$ curve was carried out at $70 \mathrm{C}$ for $0.12 \mathrm{M} \mathrm{PB}$ and $81 \mathrm{C}$ for $0.41 \mathrm{M}$ PB. The higher temperatures were used to correct for the higher melting temperature of DNA in $0.41 \mathrm{M}$ salt.

Table I, A and B presents the results of a variety of least squares fits to the data. The tables start with the results of an unconstrained fit. This is the "best fit" possible for the data. The second fits show the results when the single copy rate from the renaturation at one temperature is forced on the Cot curve at the other temperature. This calculation gives another measure of the real difference between the slow component rates at the different temperatures. If the rate constant from the fit of one set of data can be fit to another set of data with little change in the quality of the fit (measured by the goodness of fit criterion) the data are not substantially different. These fits suggest the difference between the $60 \mathrm{C}$ and $70 \mathrm{C}$ Cot curves are not significant.

A third set of fits is included to test for a small fraction of sequences renaturing at rate of 0.0004 liter-sec/mol with a Cot $1 / 2$ of 2500 . These fits indicate that our measurements cannot exclude the possibility of a very slowly renaturing fraction. The dashed lines in Figure 1, A and B show how this hypothetical component would renature.

From both of these measurements it appears that about $60 \%$ of pea DNA is repetitive with an average Cot $1 / 2$ of 1 and another $25 \%$ is less repetitive, with a Cot $1 / 2$ of 350 corresponding to a genome size of $0.39 \mathrm{pg}$. There is not a substantial difference between the renaturation at $60 \mathrm{C}$ and at $70 \mathrm{C}$.

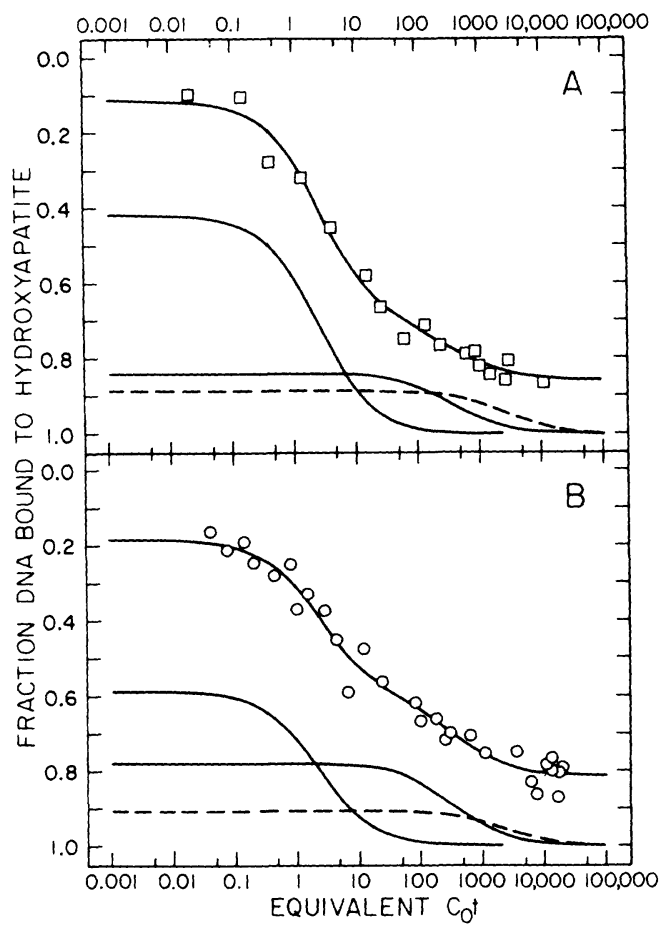

FIG. 1. Renaturation of pea DNA measured by HAP binding. Denatured 350-nucleotide pea DNA was renatured in $0.12 \mathrm{M} \mathrm{PB}$ and $0.41 \mathrm{M} \mathrm{PB}$ at $60 \mathrm{C}$ and $71 \mathrm{C}\left(\mathrm{T}_{\mathrm{m}}-25 \mathrm{C}\right)$ or $70 \mathrm{C}$ and $81 \mathrm{C}\left(\mathrm{T}_{\mathrm{m}}-15 \mathrm{C}\right)$, respectively. The single-stranded fraction was determined by HAP chromatography. Equivalent $\mathrm{Cot}$ is the Cot (mol/liter-sec) times salt concentration factors of 1 for 0.12 M PB incubations and 5 for 0.41 M PB incubations (2). Solid lines plotted show the best least squares fit to the data. Dashed lines show the contribution of a component with a rate of 0.0004 liter-sec/mol. A: renaturation at $T_{m}-25 C ; B$ : renaturation at $T_{m}-15 C$.
TABLE 1

RENATURATION OF 350 NUCLEOTIIE PEA DNA FRAGMENTS AT 60 C AND 70 C RENATURATION MEASURED BY HYDROXYAPATITE BINDING

\begin{tabular}{|c|c|c|c|c|c|}
\hline & Component & Fraction & Rate & $\operatorname{Cot} 1 / 2$ & $\begin{array}{l}\text { Repetition } \\
\text { frequency }\end{array}$ \\
\hline \multirow[t]{2}{*}{ Unconst } & ained fits: & (no parameters & fixed) & & \\
\hline & 1 & 0.114 & $>50$ & 0.02 & $>20000$ \\
\hline \multirow[t]{2}{*}{$\left(T_{m}^{60 C}-25 C\right)$} & 2 & $\begin{array}{c}0.583 \\
( \pm 0.046)\end{array}$ & $\begin{array}{c}0.399 \\
( \pm 0.128)\end{array}$ & 2.51 & 138 \\
\hline & 3 & $\begin{array}{r}0.160 \\
(-0.043)\end{array}$ & $\begin{array}{c}0.00288 \\
(+0.00315)\end{array}$ & 347 & 1 \\
\hline
\end{tabular}

Final fraction unreacted: $0.143+0.029$

\begin{tabular}{|c|c|c|c|c|c|}
\hline \multirow{3}{*}{$\left(\mathrm{T}_{\mathrm{m}}^{70 \mathrm{C}} \mathrm{C}^{-15} \mathrm{C}\right)$} & 1 & $\begin{array}{ll}0 & 184\end{array}$ & $>50$ & 0.02 & $>20000$ \\
\hline & 2 & $\begin{array}{r}0.411 \\
(+0.043)\end{array}$ & $\begin{array}{c}0.452 \\
(+0.174)\end{array}$ & 2.21 & 148 \\
\hline & 3 & 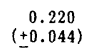 & $\begin{array}{c}0.00305 \\
+0.00202)\end{array}$ & 328 & \\
\hline
\end{tabular}

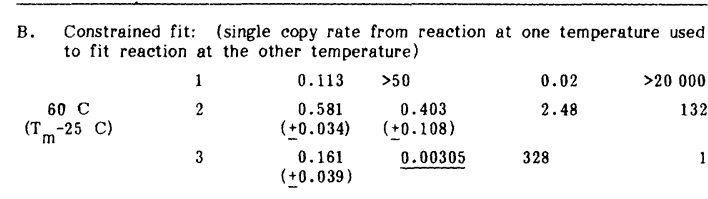

Final fraction unreacted: $0.145 \pm 0.018$

\begin{tabular}{|c|c|c|c|c|c|}
\hline \multirow{3}{*}{$\left(\begin{array}{c}70 \mathrm{C} \\
\left(\mathrm{T}^{-15} \mathrm{C}\right)\end{array}\right.$} & 1 & 0.184 & $>50$ & 0.02 & $>20000$ \\
\hline & 2 & $\begin{array}{r}0.414 \\
(+0.029)\end{array}$ & $\begin{array}{c}0.443 \\
(+0.130)\end{array}$ & 2.25 & 154 \\
\hline & 3 & $\begin{array}{c}0.217 \\
+0.031)\end{array}$ & $\underline{0.00288}$ & 347 & 1 \\
\hline
\end{tabular}

Final fraction unreacted: $0.185+0.013$

\begin{tabular}{|c|c|c|c|c|c|}
\hline \multirow[t]{3}{*}{$\begin{array}{l}\text { Constrair } \\
\text { rate } 0.0\end{array}$} & \multicolumn{3}{|c|}{ (three fitted components single } & \multicolumn{2}{|c|}{ copy component with } \\
\hline & 1 & 0.0650 & $>50$ & 0.02 & $>125000$ \\
\hline & 2 & $\begin{array}{c}0.282 \\
( \pm 0.108)\end{array}$ & $\begin{array}{c}2.74 \\
(+2.79)\end{array}$ & 0.365 & 6850 \\
\hline \multirow[t]{5}{*}{$\left(T_{m}^{60 C}\right.$} & 3 & $\begin{array}{c}0.428 \\
( \pm 0.111)\end{array}$ & $\begin{array}{r}0.100 \\
(+0.057)\end{array}$ & 10 & 250 \\
\hline & 4 & $\begin{array}{r}0.116 \\
( \pm 0.050)\end{array}$ & $\underline{0.00040}$ & 2500 & 1 \\
\hline & \multicolumn{5}{|c|}{ Final fraction unreacted: $0.109 \pm 0.033$} \\
\hline & 1 & 0.179 & $>50$ & 0.02 & $>125000$ \\
\hline & 2 & $\begin{array}{c}0.382 \\
( \pm 0.070)\end{array}$ & $\begin{array}{r}0.547 \\
(+0.296)\end{array}$ & 1.83 & 1367 \\
\hline \multirow[t]{2}{*}{ 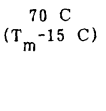 } & 3 & $\begin{array}{c}0.172 \\
( \pm 0.073)\end{array}$ & $\begin{array}{c}0.0103 \\
( \pm 0.0166)\end{array}$ & 97 & 26 \\
\hline & 4 & $\begin{array}{r}0.096 \\
( \pm 0.084)\end{array}$ & 0.00040 & 2500 & \\
\hline
\end{tabular}

Optical Cot Curves. HAP fractionation measures the formation of duplex-containing complexes. Strands containing duplexes longer than 20 to 40 nucleotides are retained on HAP although a large fraction of the retained strands may be single-stranded. Repeated sequences 300 nucleotides long separated by single copy sequences of equal length would cause the amount of DNA bound to HAP to be twice the actual amount of repetitive sequences.

Optical renaturation-measuring the fraction duplex by renaturing the DNA in a spectrophotometer-measures the true duplex fraction in the DNA. Single strand ends of duplexed molecules contribute no more to the hyperchromicity measurement than unduplexed single strand molecules.

Figure 2, A and B displays the renaturation of pea DNA at 60 $\mathrm{C}$ and $66 \mathrm{C}$ in the spectrophotometer. These curves show the same large repetitive fraction seen in the HAP Cot curves. In these curves it is about $70 \%$. Again, a number of multicomponent curves were fit to the data. Table II, A and B shows the results of these fits. The first fit for each set of data is the best unconstrained twocomponent fit. The second fit includes an additional slow component with a Cot $1 / 2$ of 5,000 which corresponds to a 3- to 5 -pg genome size. 


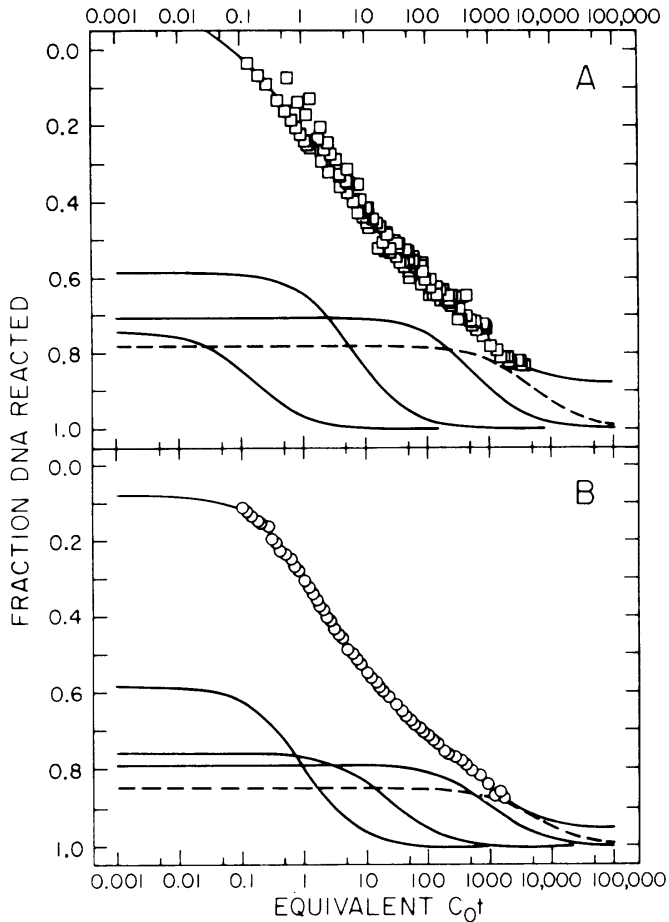

FIG. 2. Optical renaturation of pea DNA. Pea DNA fragments (350nucleotide) were denatured and renatured in a water-jacketed spectrophotometer chamber. Samples were incubated in $0.12 \mathrm{M} \mathrm{PB}$ and $0.41 \mathrm{M} \mathrm{PB}$ at $60 \mathrm{C}$ and $71 \mathrm{C}$ and in $0.12 \mathrm{M} \mathrm{PB}$ at $66 \mathrm{C}$. Fraction DNA reacted is the fraction of hyperchromicity lost after renaturation. Equivalent Cot was calculated as in Figure 1. Solid lines plotted show the results of the best least squares fits to the data. Dashed lines show the contribution of a component renaturing with a rate of $0.0002 \mathrm{liter}-\mathrm{sec} / \mathrm{mol}$. A: renaturation at $T_{m}-25 C$; B: renaturation at $T_{m}-19 C$.

A comparison of these data with the HAP Cot curves indicates that the rate constants for the components are not significantly different.

Renaturation of Labeled Slowly Renaturing DNA. Both types of renaturation curves which we have done suggest that there are two major components in the pea genome. The slow component reanneals quite rapidly, about 10 times faster than that expected from the 5-pg genome size predicted from a nuclear DNA content of $9.7 \mathrm{pg}$ (1). Because of the poor termination data and small fraction of the DNA in the complex component it is difficult to rule out a minor component at HAP curves with a $\operatorname{Cot} 1 / 2$ of 2,500 .

We have increased the sensitivity of our measurement more than 4-fold by isolating a slowly renaturing fraction of the genome, labeling it in vitro with ${ }^{125} \mathrm{I}$ and driving that tracer with whole-pea DNA. Pea DNA was renatured to Cot 400 and the single strand fraction separated on HAP. This material was labeled with ${ }^{125} \mathrm{I}$ using the Commerford $(4,6)$ procedure and driven by whole unlabeled DNA. Fifteen per cent of the DNA was isolated and labeled for this experiment so a $10 \%$ single copy fraction in whole DNA should appear as more than $50 \%$ of the DNA after the purification. The renaturation curve in Figure 3 (Table III shows the results of the unconstrained fit) does not indicate any component with a Cot $1 / 2$ greater than 500 .

\section{DISCUSSION}

These measurements are all in good agreement as to the fraction of the genome in the repetitive component. The HAP Cot curves suggest that at least $60 \%$ of the DNA is repetitive while the optical Cot curves indicate that about $70 \%$ is repetitive. Both curves show the same kinetic components. The fast components are centered at $\operatorname{Cot} 1$, the slow component around Cot 500 . The renaturation of the isolated slow component DNA driven by unfractionated pea DNA shows the same slow component.
TABLE II

RENATURATION OF PEA DNA FRAGMENTS AT $60 \quad \mathrm{C}$ and $66 \quad \mathrm{C}$ RENATURATION MEASURED OPTICALLY

\begin{tabular}{|c|c|c|c|c|c|}
\hline & Component & Fraction & Rate & $\operatorname{Cot} 1 / 2$ & $\begin{array}{l}\text { Repetition } \\
\text { frequency }\end{array}$ \\
\hline \multirow[t]{2}{*}{ Uneonst } & rained fit: & (no parameters & (fixed) & & \\
\hline & 1 & $\begin{array}{c}0.261 \\
(+0.181)\end{array}$ & $\begin{array}{r}6.70 \\
(+12.9)\end{array}$ & 0.15 & 3800 \\
\hline \multirow[t]{2}{*}{$\begin{array}{c}60 \mathrm{C} \\
\left(\mathrm{T}_{\mathrm{m}}{ }^{-25 \mathrm{C}}\right)\end{array}$} & 2 & $\begin{array}{c}0.414 \\
(+0.051)\end{array}$ & $\begin{array}{c}0.167 \\
(+0.046)\end{array}$ & 6.0 & 95 \\
\hline & 3 & $\begin{array}{c}0.295 \\
(+0.016)\end{array}$ & $\begin{array}{c}0.00176 \\
(+0.00040)\end{array}$ & 568.2 & 1 \\
\hline
\end{tabular}

\begin{tabular}{|c|c|c|c|c|c|}
\hline \multirow{4}{*}{$\left(\begin{array}{c}66 \mathrm{C} \\
\left.\mathrm{m}^{-19} \mathrm{C}\right)\end{array}\right.$} & 1 & 0.071 & $>100$ & 0.01 & $>100000$ \\
\hline & 2 & $\begin{array}{c}0.423 \\
(+0.0112)\end{array}$ & $\begin{array}{c}1.08 \\
(+0.078)\end{array}$ & 0.926 & 1030 \\
\hline & 3 & $\begin{array}{c}0.246 \\
(+0.010)\end{array}$ & $\begin{array}{c}0.0467 \\
( \pm 0.0075)\end{array}$ & 21.41 & 45 \\
\hline & 4 & $\begin{array}{c}0.214 \\
(+0.015)\end{array}$ & $\begin{array}{r}0.00104 \\
( \pm 0.00031)\end{array}$ & 961.5 & 1 \\
\hline
\end{tabular}

Final fraction unreacted: $0.046+0.022$

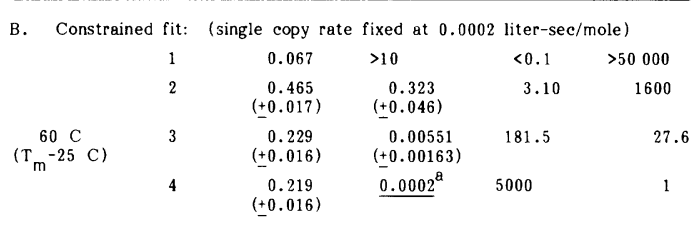

Final fraction unreacted: $0.020^{\mathrm{a}}$

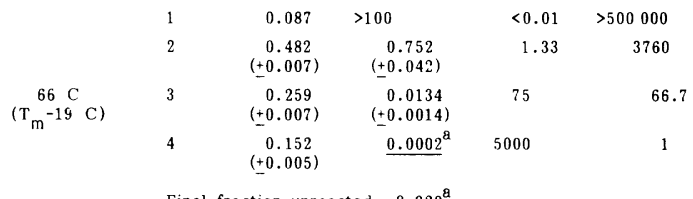

Final fraction unreacted: $\underline{0.020^{\mathrm{a}}}$

${ }^{a}$ These values were fixed to allow the program to do the fit.

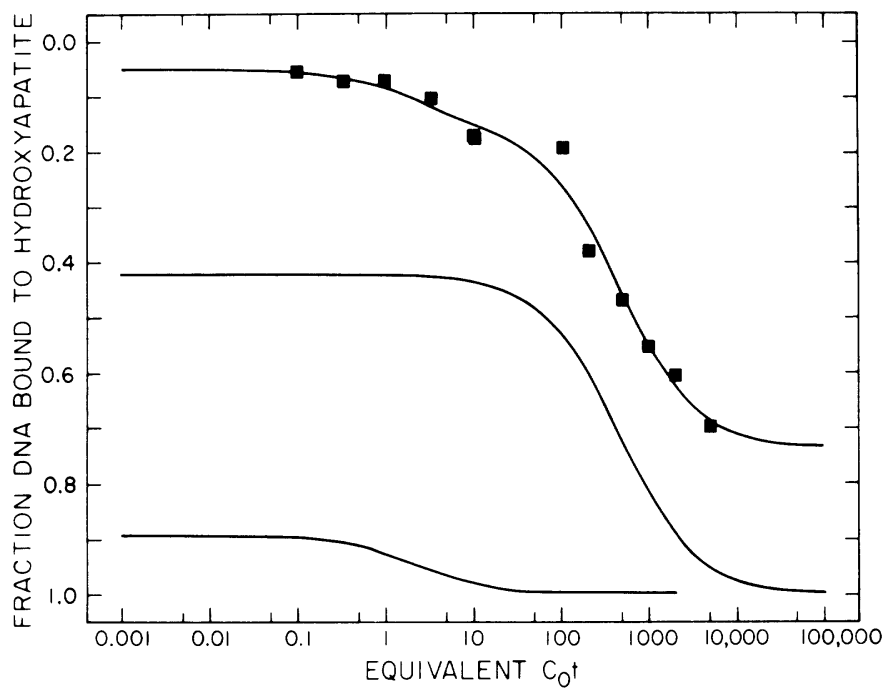

FIG. 3. Renaturation of ${ }^{125}$ I labeled single copy pea DNA. A fraction of pea DNA $(15 \%)$ enriched in single copy sequences was isolated and labeled as described in the text. This labeled fraction was driven by a 5,000 -fold excess of unfractionated pea DNA to the equivalent Cots shown. The renaturation of the driver DNA (not shown) and ${ }^{125}$ I single copy tracer was measured after fractionation on hydroxyapatite. The solid line shows the best least squares fit with the components described in Table III. (ם) fraction of ${ }^{125}$ I DNA in duplex.

The conclusion that about $60 \%$ or more of the DNA sequences in the pea genome are repeated is a strong one. Changes in the incubation temperature which should melt poorly matched duplexes do not alter the renaturation curve. The large fraction 
TABLE III

RENATURATION OF ${ }^{125}$ I LABELED SLOWLY RENATURING PEA DNA

\begin{tabular}{ccccc}
\hline Component & Fraction & Rate & Cot 1/2 & $\begin{array}{r}\text { Repetition } \\
\text { frequency }\end{array}$ \\
\hline 1 & $\begin{array}{c}0.109 \\
( \pm 0.051) \\
0.580 \\
( \pm 0.053)\end{array}$ & $\begin{array}{c}0.463 \\
( \pm 0.972) \\
0.00215 \\
\pm 0.00082)\end{array}$ & 2.16 & 215 \\
& Final fraction unreacted: & $0.263 \pm 0.044$ & 1 \\
& & &
\end{tabular}

repetitive is really due to duplexed DNA, not to single strand tails or closely spaced duplexes. We are therefore confident that the fraction of repeated sequences we have determined is correct.

There is also good agreement on the Cot $1 / 2$ of the slowly renaturing complex component-about 450 . If this slow component represents the single copy DNA of the pea its genome size is about $0.5 \mathrm{pg}$. Unfortunately it is difficult to be certain that the final fraction unreacted does not contain a more slowly renaturing component. Ten per cent of the DNA could easily be renaturing but hidden in the final unreacted fraction of either HAP Cot curve or the optical Cot curves. The renaturation experiment displayed in Figure 3 sets an upper limit on the fraction of this hypothetical very slow component below $5 \%$ of the pea genome.

Similar discrepancies have been also found in the cotton (14) and tobacco (16) genomes. Thompson (12) has reported a 15 to $20 \%$ slowly renaturing component of pea DNA in $4 \mathrm{M} \mathrm{NaClO}_{4}$ $0.18 \mathrm{M}$ Na phosphate buffer with a Cot $1 \frac{1}{2}$ rate which is consistent with a genome size of $5 \mathrm{pg}$ when corrected for the accelerating effect of $\mathrm{NaClO}_{4}$. However, Walbot and Goldberg (15) have also reported a Cot $1 \frac{1}{2}$ of 500 for the slowest component of pea DNA under standard conditions $(0.12 \mathrm{M} \mathrm{PB}, 60 \mathrm{C})$. We believe that the true size of the pea genome is $5 \times 10^{8}$ base pairs. This is in contrast to the $5 \times 10^{9}$ base pairs/genome based on the chemical determination of DNA in nuclei isolated from pea seedling stem tips
(1) or root tips $(9,13)$. We now know (8) that the majority of stem cells of the pea are $4 \mathrm{X}$ to $16 \mathrm{X}$ polyploid. Walbot and Dure (14) made a similar discovery on measuring the kinetics of reassociation of cotton DNA. We believe that the complexity measured from the rate of renaturation of single copy DNA $(3,7)$ provides a more accurate value for the genome size.

\section{LITERATURE CITED}

1. BiRnstiel ML, MIH Chipchase, WG FLAMm 1964 On the chemistry and organization of nucleolar proteins. Biochim Biophys Acta 87: 111-122

2. Britten RJ, DE Graham, BR NeUfeLd 1973 An analysis of repeating DNA sequences by reassociation. Methods Enzymol 29: 363-418

$\rightarrow$ BRITTEN RJ, DE KoHNE 1968 Repeated sequences in DNA. Science 161: 529-540

4. COMMERFORD SL 1971 Iodination of nucleic acids in vitro. Biochemistry 10: 1992-2000

5. Davidson EH, Ga Galau, RC Angerer, RJ Britten 1974 Comparative aspect of DNA organization in metazoa. Chromosoma 51: 253-259

6. HOLMES DS, 3 BONNER 1974 Sequence composition of rat nuclear deoxyribonucleic acid and high molecular weight nuclear ribonucleic acid. Biochemistry 13: 841-848

7. LAIRD CD 1971 Chromatid structure: relationship between DNA content and nucleotide sequence diversity. Chromosoma 32: 378-406

$\rightarrow$ LibBenga KR, JG TorRey 1973 Hormone-induced endoreduplication prior to mitosis. Am J Bot 60: 293-299

9. MCLEISCH J, N SUNDERLAND 1961 Measurements of deoxyribonucleic acid (DNA) in higher plants by Feulgen photometry and chemical methods. Exp Cell Res 24: 527-540

10. Pearson WR, eh Davidson, RJ Britten 1977 Program for least squares analysis of reassociation and hybridization data. Nucleic Acids Res 4: 1727-1737

11. Smith DB, J RimpaU, RB FLAVELL 1976 Interspersion of different repeated sequences in the wheat genome revealed by interspecies DNA/DNA hybridization. Nucleic Acids Res. 3 2811-2825

12. TномPSON WF 1976 Sequence organization in pea DNA. Carnegie Institution Yearbook 75 : $356-362$

13. VAN'T HOFF J, AH SPARRow 1963 A relationship between DNA content, nuclear volume, and minimum mitotic cycle time. Proc Nat Acad Sci USA 49: 897-902

14. WALBOT V, LS DURE III 1976 Developmental biochemistry of cotton seed embryogenesis and germination. J Mol Biol 101: 503-536

15. WALBot V, RB GOLDBERG 1978 DNA sequence organization in plants. In E Davis, T Hall, eds, Nucleic Acids in Plants. CRC Press, Cleveland Ohio. In press

16. ZimmeRMAN JL, RB GoldBerg 1977 DNA sequence organization in the genome of Nicotiana tabacum. Chromosoma 59: 227-252 